\title{
Wirausaha Es Krim dan Puding Sedot Temulawak Penambah Nafsu Makan Oleh Kader Posyandu Desa Sukokerto Kecamatan Sukowono Jember
}

\author{
Ika Rahmawati Sutejo \\ Laboratorium Biokimia, Fakultas Kedokteran, Universitas Jember \\ Nur Hisamuddin \\ Fakultas Ekonomi dan Bisnis, Universitas Jember \\ ikarahmawati.fk@unej.ac.id
}

\begin{abstract}
Abstrak
Angka kurang gizi pada anak di kabupaten Jember merupakan salah satu tertinggi di Jawa Timur, yaitu sebesar 8.035 Balita. Hal ini membuat permasalahan kesehatan yang dihadapi kader posyandu fokus pada gangguan gizi ini. Terapi gizi/nutrisi juga merupakan penanganan utama untuk kasus tersebut. Kader posyandu merasa pengetahuan gizi mereka terbatas, sehingga makanan sehat yang disiapkan untuk kegiatan posyandu kurang bervariatif. Selain itu kader ingin memanfaatkan pengetahuan \& keterampilan mereka untuk mendapatkan tambahan penghasilan sehingga meningkatkan perekonomian keluarga.

Es Krim dan pudot (puding sedot) merupakan 2 macam makanan yang disukai oleh anak karena texture yang lembut dan rasanya manis. Kedua makanan ini sangat cocok digunakan sebagai makanan pendamping untuk meningkatkan nafsu makan dan menambah berat badan balita gizi buruk maupun anak-anak sehat pada umumnya. Kandungan gizi kedua makanan ini cukup lengkap, terdiri dari karbohidrat/gula, protein, lemak, vitamin dan mineral dengan tambahan sari temulawak yang telah terbukti dapat meningkatkan nafsu makan.

Tim pelaksana pengabdian masyarakat memberikan solusi kepada mitra kader posyandu 72 dan 74 Desa Sukokerto Kecamatan Sukowono berupa transfer pengetahuan tentang nutrisi, pelatihan pembuatan es krim dan puding temulawak serta pendampingan kewirausahaan. Mitra juga diberikan peralatan yang dibutuhkan untuk pembuatan makanan, pengemasan hingga pemasaran produknya. Target yang dicapai dari kegiatan ini adalah mitra mampu membuat es krim dan pudot temulawak penambah nafsu makan anak serta mampu mengelola dan memasarkan produk wirasusaha secara mandiri.
\end{abstract}

Kata Kunci: Kader Posyandu, Wirausaha, Es Krim, Puding Sedot, Temulawak 


\section{PENDAHULUAN}

Angka kurang gizi pada anak di kabupaten Jember merupakan salah satu tertinggi di Jawa Timur, yaitu sebesar 8.035 Balita. Komposisi balita Desa Sukokerto Kecamatan Sukowono sendiri sebesar $26 \%$ dari total penduduk. Hal ini membuat permasalahan kesehatan yang dihadapi kader posyandu desa fokus pada gangguan gizi ini. Kegiatan pelayanan kesehatan tingkat keluarga terkait permasalahan tersebut dilaksanakan melalui posyandu. Saat ini terdapat 6 posyandu di desa Sukokerto yang aktif melaksanakan pelayanan kesehatan sebulan sekali untuk balita. Kegiatan yang dilaksanakan berupa pemeriksaan kesehatan dan terapi sederhana, pengisian KMS, konseling/edukasi, imunisasi dan upaya peningkatan gizi. Seluruh kegiatan tersebut dilakukan kader kesehatan dibimbing bidan dan dokter puskesmas (Anonim, 2014). Terdapat 7 orang kader di tiap-tiap 6 pokja penyelenggara posyandu Desa Sukokerto, yang rutin berkoordinasi dan mendapatkan pelatihan dari petugas kesehatan Puskesmas Sukowono.

Masalah kesehatan yang sering dijumpai saat pelaksanaan posyandu desa Sukokerto adalah kurang gizi dan infeksi (diare dan infeksi saluran napas) balita. Selain penanganan berupa terapi obat oleh dokter dan bidan puskesmas, terapi nutrisi tidak kalah penting untuk kasus-kasus tersebut (Syarif et al., 2014). Dokter/bidan puskesmas memberikan informasi makanan/zat gizi yang dianjurkan atau dilarang dikonsumsi. Kader posyandu bertugas menyiapkan makanan sehat tambahan untuk diberikan pada balita saat kegiatan posyandu. Kader dituntut untuk menyesuaikan menu makanan dengan permasalahan balita, misalnya untuk balita seringkali dipilih menu sup kacang hijau karena mempunyai kandungan protein tinggi yang baik untuk pertumbuhan anak.

Dari wawancara terhadap kader posyandu 72 dan 74 desa Sukokerto, beberapa permasalahan saat ini adalah: 1) kader posyandu merasa pengetahuan mereka tentang nutrisi dan cara pengolahan makanan masih terbatas, 2) jenis makanan yang disiapkan untuk kegiatan posyandu kurang bervariatif, 3) keinginan kader meningkatkan taraf perekonomian keluarga., 4) kurangnya pengetahuan mengenai kewirausahaan, hal ini berkaitan dengan permasalahan sebelumnya, yaitu keinginan kuat untuk menciptakan usaha mandiri oleh kader posyandu.

Tim pelaksana pengabdian masyarakat memberikan solusi bagi permasalahan kader posyandu melalui kegiatan pengabdian masyarakat berupa penyuluhan mengenai nutrisi dan cara pengolahan makanan sehat, menggagas pembentukan wirausaha es krim dan pudot penambah nafsu makan, pendampingan produksi, sampai pemasaran. Es Krim dan pudot merupakan 2 macam makanan yang disukai oleh anak karena texture yang lembut dan rasanya manis. Kedua makanan ini cocok digunakan sebagai makanan pendamping peningkat nafsu makan dan penambah berat badan balita gizi buruk maupun anak-anak sehat pada umumnya. Kandungan gizi kedua makanan ini cukup lengkap, terdiri dari karbohidrat/gula, protein, lemak, vitamin dan mineral, dengan tambahan sari temulawak sebagai bahan aktif yang telah terukti dapat meningkatkan nafsu makan (Amaliah, 2017). Temulawak merupakan tanaman toga 
yang mudah dijumpai, banyak ditanam oleh kader posyandu di lahan sekitar rumah, harganya murah, dan belum banyak dimanfaatkan.

Kegiatan ini meningkatkan peran aktif kader posyandu untuk perbaikan status gizi dan kesehatan masyarakat, juga meningkatkan taraf perekonomian masyarakat dengan menambah pemasukan kader dan keluarganya. Selain itu, kegiatan ini diharapkan dapat menjadi inisiasi dan percontohan untuk kader posyandu desa dan kecamatan lain di Kabupaten Jember.

\section{METODE}

Kegiatan ini terdiri dari beberapa tahapan, yang menekankan kemandirian kader posyandu 72 dan 74 desa Sukokerto Kecamatan Sukowono. Tahapan yang dilakukan berupa:

1) Penyuluhan mengenai metode pengolahan makanan yang baik, komposisi gizi dan kebutuhan nutrisi berdasar penyakit.

2) Pendampingan membuat menu makanan tambahan yang bervariatif untuk kegiatan posyandu. Variasai menu diwujudkan dengan tersedianya es krim dan pudot temulawak penambah nafsu makan anak pada kegiatan posyandu.

3) Menggagas pembentukan wirausaha es krim dan pudot temulawak yang digawangi oleh mitra.

4) Pendampingan produksi dan pemasaran produk hasil wirausaha mitra.

Kegiatan ini dilakukan pada bulan Agustus-Desember 2017. Kegiatan utama ditekankan pada pelatihan pembuatan es krim dan pudot temulawak penambah nafsu makan.

\section{HASIL DAN PEMBAHASAN}

Sebelum tim pelaksana pengabdian masyarakat melatihkan pembuatan puding sedot dan es krim temulawak penambah nafsu makan pada mitra, komposisi bahan yang dibutuhkan telah diujicoba sehingga pelatihan bisa berjalan efektif dan efisien. Tekstur dan rasa puding sedot dan es krim temulawak yang dibuat juga telah melewati uji rasa/organoleptik. Optimasi resep dilakukan beberapa kali sehingga menghasilkan konsistensi puding sedot dan es krim temulawak yang baik dan rasa yang enak sehingga bisa disukai oleh anak-anak. Temulawak sendiri merupakan bahan yang mempunyai bau dan rasa yang khas, yang jika dicampurkan dalam jumlah terlalu banyak menjadikan rasa makanan menjadi tidak enak dan tidak disukai (Yanis et al.,2014). Pencampuran bahan puding sedot dan es krim temulawak memerlukan waktu masing-masing 30-45 menit sedangkan memadatkan puding sedot dan es krim temulawak memerlukan waktu 24 jam.

Pelatihan dan pendampingan membuat puding sedot dan es krim temulawak penambah nafsu makan dilakukan oleh tim. Tim pelaksana pengabdian masyarakat menyiapkan bahan-bahan dan peralatan yang dibutuhkan. Kader posyandu menjadi pihak utama dalam proses produksi puding sedot dan es krim temulawak tersebut, sehingga diberikan pelatihan praktek membuat puding sedot dan es krim temulawak 
secara langsung pada Oktober 2017. Dalam pelatihan pembuatan puding sedot dan es krim temulawak ini terdapat 12 orang kader yang mengikuti (Gambar 1). Praktek dan diskusi berlangsung interaktif, karena kader tertarik dan ingin mengembangkan produksi puding sedot dan es krim temulawak dengan komposisi bahan tambahan lain. Pada saat pelatihan juga diserahkan peralatan yang diperlukan dalam pembuatan puding sedot dan es krim temulawak, yaitu mixer, alat set masak panci, freezer, dan termos es (Gambar 2). Setiap pembuatan 1 resep puding sedot menghasilkan 20 pieces puding dan 1 resep es krim temulawak menghasilkan 10 kemasan es krim.
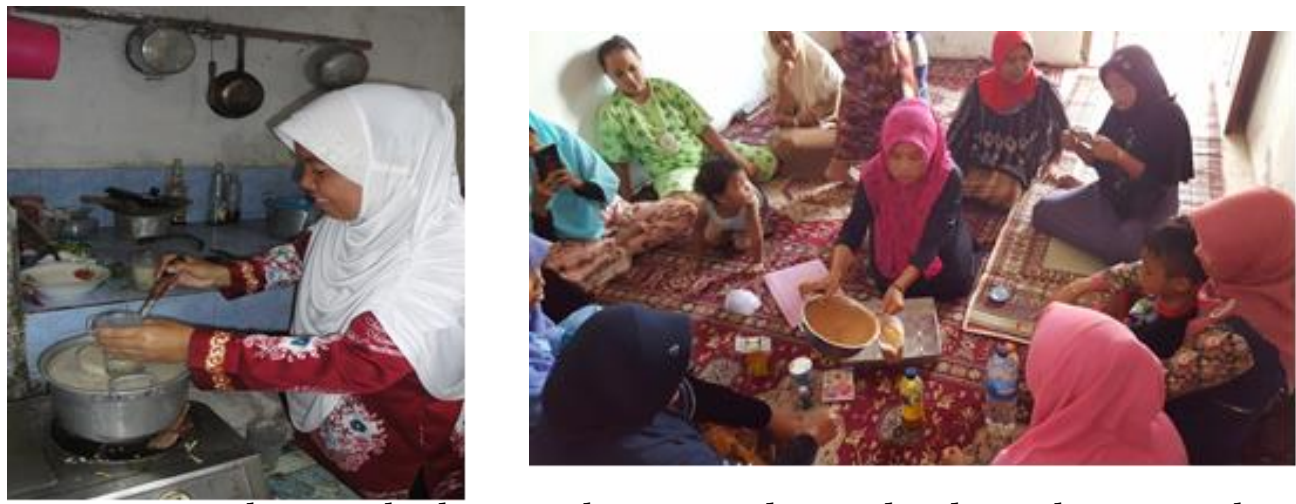

Gambar l. Pelatihan pembuatan puding sedot dan es krim temulawak

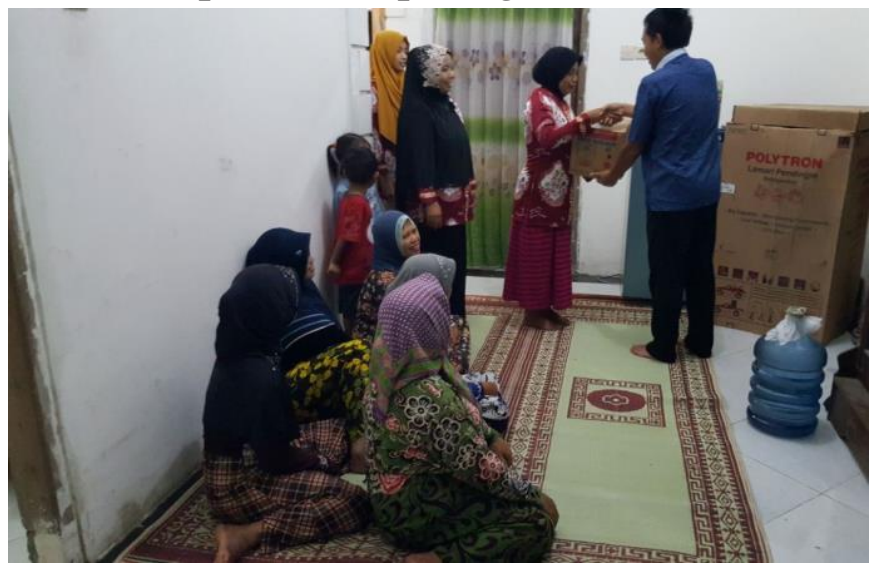

Gambar 2. Pemberian peralatan

Setelah pelatihan, kader diminta untuk membuat puding sedot dan es krim temulawak secara mandiri untuk memenuhi kebutuhan posyandu, kemudian karena animo konsumen yang besar beberapa kader mulai membuat untuk dijual di lingkungan sekitar. Kegiatan ini menyimpulkan bahwa puding sedot dan es krim temulawak yang dibuat disukai oleh anak-anak, harga produk ini relatif murah dan dipasarkan dengan harga Rp. 1000 untuk pudot dan Rp. 2000 untuk es krim (Gambar $3)$.

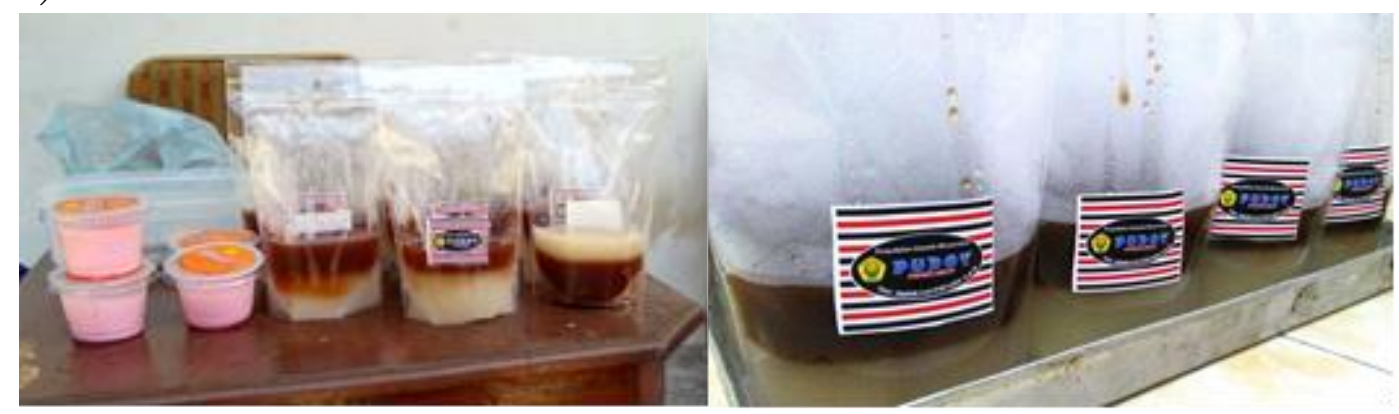


Gambar 3. Produk Es Krim dan Puding temulawak

Pada akhir kegiatan, kader posyandu juga dibantu untuk menyusun laporan keuangan. Disamping sebagai bentuk pertanggung jawaban, laporan keuangan juga berfungsi sebagai evaluasi dan perencanaan. Evaluasi atas efektif dan edisiensi pengelolaan bisnis yang dilakukan serta perencanaan untuk menjadikan usaha semakin berkembang (Sufi, 2008).

\section{PENUTUP}

\section{A. Kesimpulan}

Tim pelaksana pengabdian masyaraat bersama dengan mahasiswa melakukan upaya untuk meningkatkan tingkat pengetahuan, kemandirian, ketrampilan dan kemampuan wirausaha kader posyandu 72 dan 74 desa Sukokerto kecamatan Sukowono dalam mengatasi permasalahan gizi balita melalui upaya kesehatan promotif, yaitu penyuluhan kesehatan, pelatihan pembuatan pembuatan puding sedot dan es krim temulawak penambah nafsu makan dan pendampingan wirausaha pada bulan AgustusDesember 2017. Keberlanjutan kegiatan ini perlu diupayakan dengan sungguh-sungguh agar wirausaha tetap berjalan. Perlu dikembangkan pengemasan produk yang menarik dan layak dipasarkan ke luar kecamatan, serta inovasi untuk menambahkan produk baru maupun mengembangkan produk yang telah ada.

\section{B. Ucapan Terimakasih}

Terima kasih kepada Universitas Jember yang telah mendanai pengabdian masyarakat ini ini melalui Hibah Pengabdian kepada Masyarakat skim Pengabdian Dosen Pemula dengan pendanaa DIPA Universitas Jember tahun anggaran 2017.

\section{DAFTAR PUSTAKA}

Amaliah A. 2017. Efektifitas Infusum Temulawak terhadap Peningatan Berat Badan

Anak Prasekolah di TK Aisyiyah Bustanul Athfal Dusun Semlawang Surabayan Kecamatan Sukodadi Kabupaten Lamongan. Surya, Vol 09 No 01:16-22.

Anonim. 2014. Buku Pegangan Kader Posyandu. Kementrian Kesehatan RI.

Syarif DR, Lestari ED, Mevitalia M, Nasar SS. 2014. Buku Ajar Nutrisi Pediatrik dan Penyakit Metabolik. Jakarta: IDAI.

Sufi SY. 2008. Panduan Membuka dan Mengelola Wirausaha Catering Skala Rumah Tangga. Jakarta: Kawan Pustaka.

Yanis M., Aminah S., Handayani T, Ramdhan T., Harnanik S. 2014. Tingkat Kesukaan Konsumen terhadap Marsmallow Berbahan Baku Temulawak. Prosiding seminar 
Nasional Peranian Ramah Lingkungan Mendukung Bioindustri di Lahan Sub

Optimal: 535-544.

\section{DOKUMENTASI KEGIATAN}
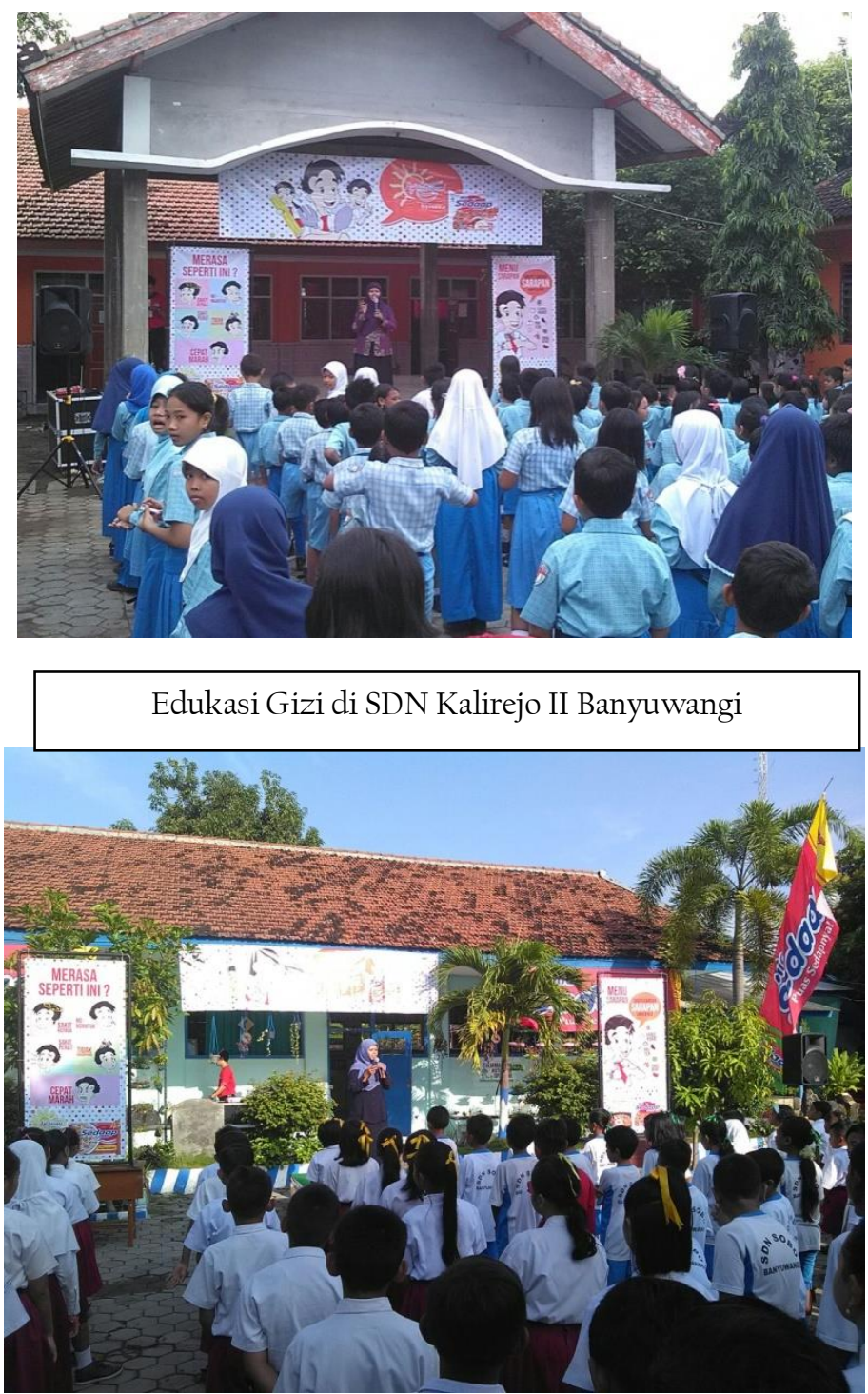

Edukasi Gizi di SDN Sobo Banyuwangi 


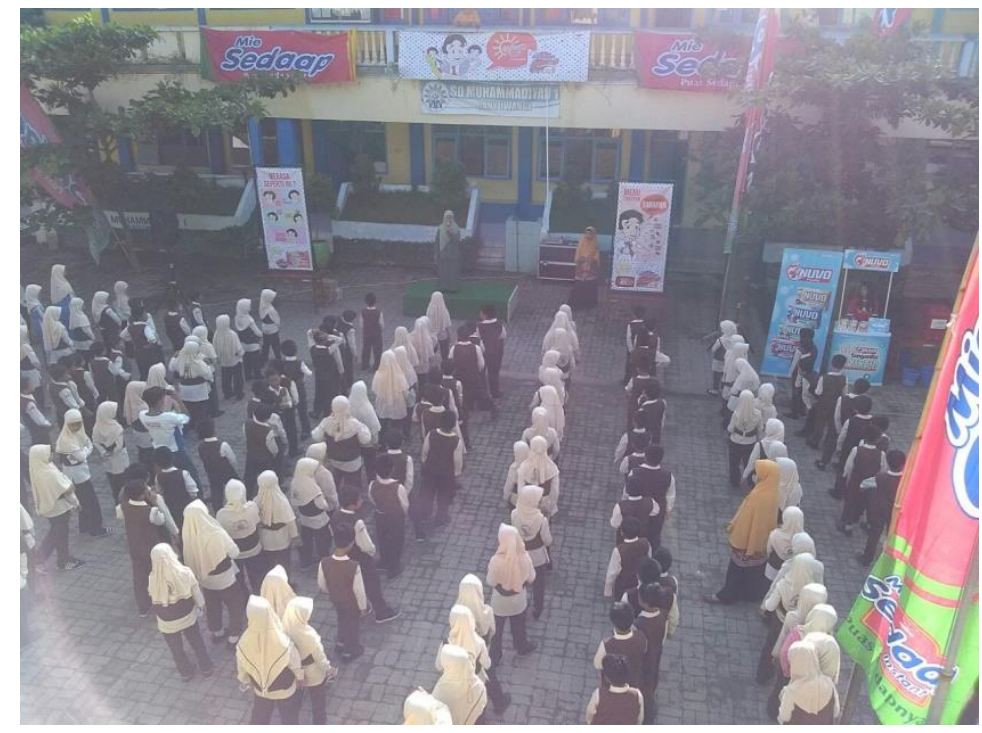

Edukasi Gizi di SD Muhammadyah Banyuwangi

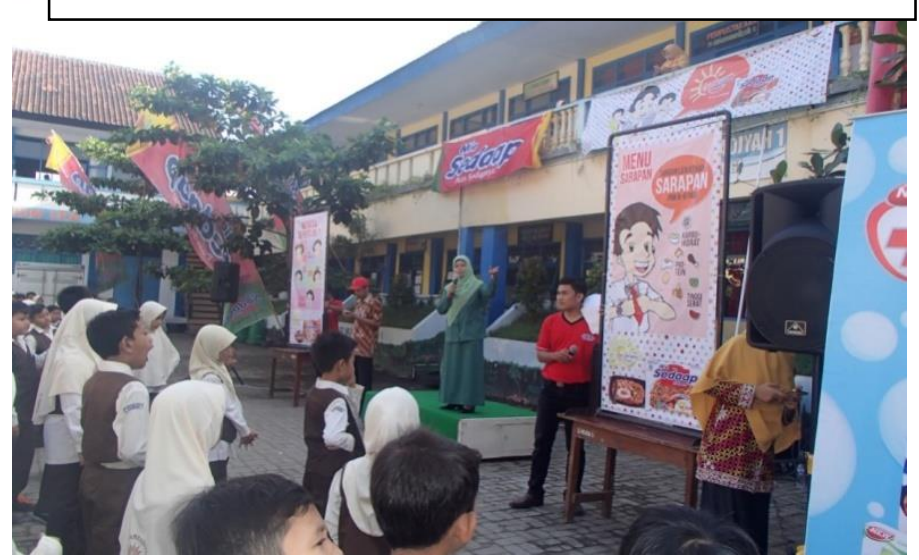

Edukasi Gizi di SD Muhammadyah Banyuwangi

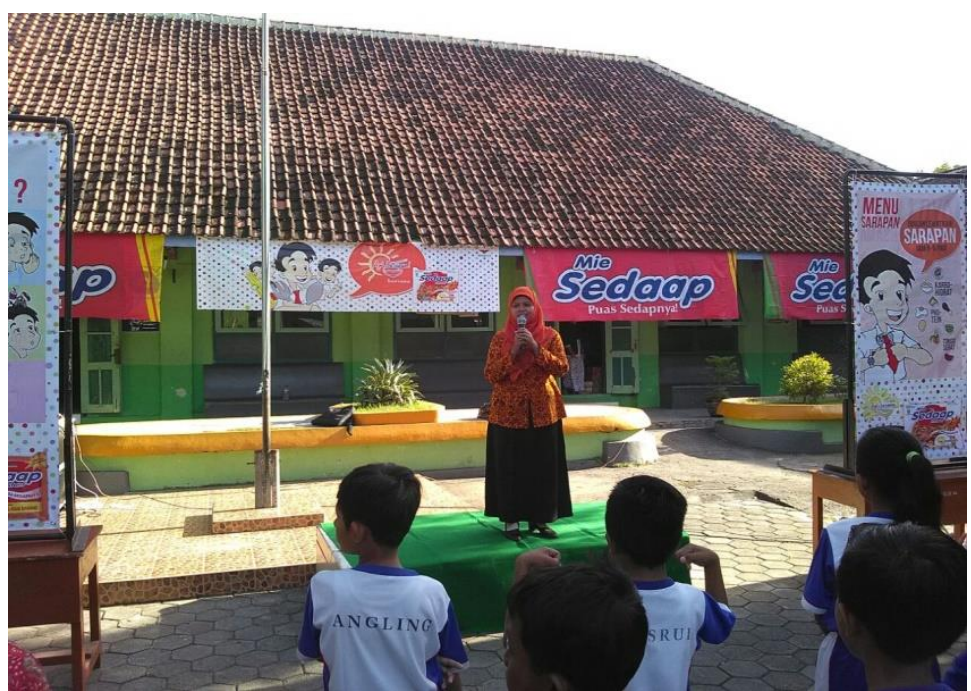

Edukasi Gizi di SDN Singotrunan Banyuwangi 


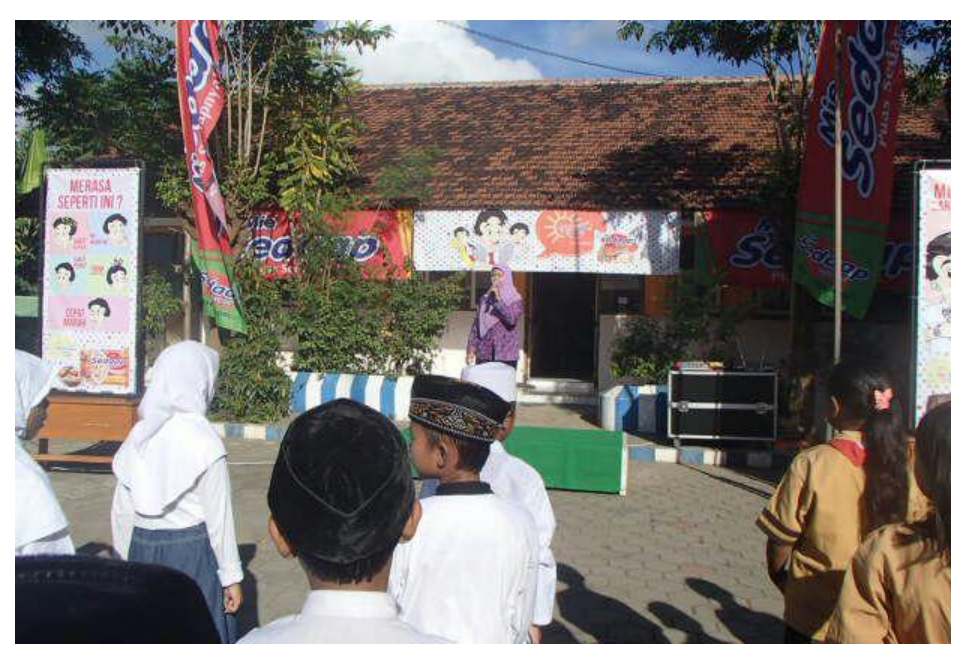

Edukasi Gizi di SDN Sumberrejo Banyuwangi 